University of Nebraska - Lincoln

DigitalCommons@University of Nebraska - Lincoln

USDA National Wildlife Research Center - Staff Publications
U.S. Department of Agriculture: Animal and Plant Health Inspection Service

2017

\title{
Low viral doses are sufficient to infect cottontail rabbits with avian influenza $A$ virus
}

\author{
J. Jeffrey Root \\ USDA/APHIS/WS National Wildlife Research Center, jeff.root@aphis.usda.gov
}

Susan A. Shriner

USDA/APHIS/WS National Wildlife Research Center, susan.a.shriner@aphis.usda.gov

Jeremy W. Ellis

USDA National Wildlife Research Center

Kaci K. VanDalen

USDA/APHIS/WS National Wildlife Research Center, kaci.vandalen@aphis.usda.gov

Heather J. Sullivan

USDA/APHIS/WS National Wildlife Research Center, Heather.Sullivan@aphis.usda.gov

Follow this and additional works at: https://digitalcommons.unl.edu/icwdm_usdanwrc

Part of the Life Sciences Commons

Root, J. Jeffrey; Shriner, Susan A.; Ellis, Jeremy W.; VanDalen, Kaci K.; and Sullivan, Heather J., "Low viral doses are sufficient to infect cottontail rabbits with avian influenza A virus" (2017). USDA National Wildlife Research Center - Staff Publications. 2003.

https://digitalcommons.unl.edu/icwdm_usdanwrc/2003

This Article is brought to you for free and open access by the U.S. Department of Agriculture: Animal and Plant Health Inspection Service at DigitalCommons@University of Nebraska - Lincoln. It has been accepted for inclusion in USDA National Wildlife Research Center - Staff Publications by an authorized administrator of DigitalCommons@University of Nebraska - Lincoln. 


\title{
Low viral doses are sufficient to infect cottontail rabbits with avian influenza A virus
}

\author{
J. Jeffrey $\operatorname{Root}^{1} \cdot$ Susan A. Shriner $^{1} \cdot$ Jeremy W. Ellis $^{1} \cdot$ Kaci K. VanDalen $^{1} \cdot$ \\ Heather J. Sullivan ${ }^{1}$
}

Received: 18 April 2017 / Accepted: 11 July 2017 / Published online: 2 August 2017

(C) Springer-Verlag GmbH Austria (Outside the USA) 2017

This document is a U.S. government work and is not subject to copyright in the United States.

\begin{abstract}
Influenza A viruses (IAVs) have been reported in wild lagomorphs in environments where they share resources with waterfowl. Recent studies have conclusively shown that a North American lagomorph, cottontail rabbits (Sylvilagus sp.), become infected following exposure to IAVs and can shed significant quantities of virus. However, the minimum infectious dose and the efficiency of various routes of infection have not been evaluated. Thirty-six cottontail rabbits were used in a dose response study assessing both the oral and nasal routes of infection. The nasal route of infection proved to be the most efficient, as all cottontail rabbits shed viral RNA following inoculation with doses as low as $10^{2}$ EID $_{50}$. The oral route of infection was less efficient, but still produced infection rates of $\geq 50 \%$ at relatively low doses (i.e., $10^{3}$ and $10^{4} \mathrm{EID}_{50}$ ). These results suggest that cottontail rabbits are highly susceptible to IAVs at low exposure doses that have been routinely observed in environments contaminated by waterfowl. Furthermore, this study supports earlier observations that cottontail rabbits may pose a biosecurity risk to poultry operations, as a virus-contaminated water source or contaminated environment, even at low viral titers, could be sufficient to initiate viral replication in cottontail rabbits.
\end{abstract}

J. Jeffrey Root

Jeff.root@aphis.usda.gov

1 United States Department of Agriculture, National Wildlife Research Center, 4101 La Porte Avenue, Fort Collins, CO 80521, USA

\section{Introduction}

Although lagomorphs (i.e., rabbits, hares, and pika) could be considered unlikely candidates in the epidemiology of avian influenza A viruses (IAVs), some lagomorph species are susceptible to multiple subtypes of these viruses [18, 28, 29]. For example, natural exposures of both highly pathogenic (HP) and low pathogenic (LP) avian influenza A viruses (IAVs) have been reported from plateau pika (Ochotona curzoniae) sampled near Qinghai Lake, China [28, 29], a location where HP H5N1 IAV has been detected on many occasions $[5,26]$. In addition, experimentally infected cottontail rabbits (Sylvilagus sp.) shed significant quantities of IAV through the oral and nasal routes [18] with the capacity to transmit IAV to mallards (Anas platyrhynchos) through shared resources [19]. Recently, a study showed that cottontail rabbits are susceptible to and shed relatively large quantities of emergent H7N9 IAV [20]. Although these field and laboratory studies have provided important information about the susceptibility of various lagomorphs to several IAVs, they have not evaluated the minimum infectious doses and the various routes of infection that are probable in natural settings for these animals.

Aside from natural infections in lagomorphs, rabbits can be commonly found in live-bird markets in many regions of the world [6, 27]. Of interest, rabbits have been previously suggested as a species that significantly increased the risk of live-bird markets testing positive for H7 IAV in the northeastern U.S. [4]. The authors were unable to fully assess the reason behind this increased risk, but suggested, among other things, that it could be associated with unknown features pertaining to the rabbits themselves [4].

The recent introduction/detection of Eurasian strain HP H5 viruses in the U.S. [9] and the subsequent detection of these and reassortant $\mathrm{H} 5$ viruses in multiple poultry 
facilities during 2015 [15] have produced enormous burdens to the poultry industry. Cottontail rabbits are very common throughout much of North America [2] and are undoubtedly part of the fauna surrounding some poultry facilities in the U.S. Hypothetically, if a cottontail rabbit were exposed to an IAV at or near a body of water within close proximity of a poultry facility, this animal could subsequently move the virus to areas adjacent to the enclosures housing the poultry. This scenario, however, may be more probable if the oral route of infection is efficient in cottontail rabbits and if high levels of viral replication can be initiated following exposures to low doses of virus, conditions characterizing the most likely exposure scenarios in natural settings. The objective of this study was to assess the efficacy of low infectious doses of IAV in cottontail rabbits by both the oral and nasal routes to further characterize the biosecurity risk that may be posed by this species. To accomplish this study, a LP H4 IAV was selected because it has been shown previously to replicate in multiple mammalian species and is a very common virus in wild bird populations in North America [14, 16-18, 21].

\section{Materials and methods}

\section{Study animals}

Thirty-six cottontail rabbits (Sylvilagus sp.) were wildcaught in north-central Colorado and were subsequently used for the experiment following a quarantine period of $\geq 14$ days. Six cottontail rabbits were assigned to each of six treatment groups representing each combination of three inoculation doses of approximately $10^{2}, 10^{3}$, and $10^{4}$ $\mathrm{EID}_{50}$ and either the oral or nasal route of inoculation. The cottontail rabbits were housed in standard rabbit racks that included a nest box, alfalfa, rabbit food (MannaPro®, Pro Formula, St. Louis, MO), a water bowl, and an enrichment toy. Water and food were replenished each day when needed. Each treatment group for the six dose/route combinations was housed in a different rabbit rack. Animal methods were approved by the National Wildlife Research Center Animal Care and Use Committee (2356).

\section{Experimental infections}

Prior to initiation of the experiment, a blood sample was taken from each cottontail while the animals were anesthetized with isoflurane anesthesia $[3,18]$ to test for antibodies reactive with IAV. The LP IAV used in this study, A/ Mallard/CO/P70F1-03/08(H4N6), which was grown and titered in SPF chicken eggs, has been described previously
[16]. On day zero of the study, all cottontail rabbits were inoculated with their respective viral dose (approximately $10^{2}, 10^{3}$, or $10^{4} \mathrm{EID}_{50}$ ) diluted in $1 \mathrm{~mL}$ (oral route) or $250 \mu \mathrm{l}$ (nasal route) of BA-1 diluent [21]. One-half $(\mathrm{n}=3)$ of each treatment group was sampled (nasal flush and oral swab using $1 \mathrm{~mL}$ of BA-1 diluent) on odd days postinfection (DPI), while the other three were sampled on even DPI through 8 DPI using the same isoflurane anesthesia methods outlined above. All animals were maintained until 18 DPI at which time the animals were anesthetized, a post-experiment blood sample was drawn, and the animals were euthanized.

\section{Laboratory testing}

Nasal flushes and oral swabs from cottontail rabbits were tested in duplicate using a real-time RT-PCR assay based on primers and probes described in [22] and conditions, equipment, and reagents described in [19]. Positive samples were defined as those yielding a two-well positive amplification with a $\mathrm{Cq}$ value of $\leq 38$. Calibrated controls based on known viral titers $\left(10^{2} \mathrm{EID}_{50} / \mathrm{mL}-10^{5} \mathrm{EID}_{50} /\right.$ $\mathrm{mL}$ ) were also tested, and 4-point standard curves were constructed. Viral RNA quantities from samples were extrapolated from the standard curves and are reported as PCR EID $_{50}$ equivalents/mL.

Pre-exposure and post-experiment serum samples were tested for the presence of antibodies to IAV group-specific antigens by the agar gel immunodiffusion (AGID) test [12]. AGID tests have the ability to detect antibodies to all IAVs $[12,23]$, but their utility in many species is unknown. Details on the use of this and other serological procedures in cottontail rabbits have been published elsewhere [18].

\section{Data analysis}

Box plots and other analyses were completed in $\mathrm{R}$ 3.0.2. [24]. The impact of inoculation dose and the route of inoculation were investigated using linear mixed-effects regression. We modeled the total RNA output (sum of viral RNA across day sampled) as a function of the following main effects: inoculation dose (DOSE, $10^{2} \mathrm{EID}_{50}, 10^{3}$ $\mathrm{EID}_{50}$, or $10^{4} \mathrm{EID}_{50}$ ), route of inoculation (ROUTE, oral or nasal), sample type (TYPE, oral swab or nasal wash), and interactions between these main effects. Individual animals were modelled as random effects. Models with the three main effects, main effects and two-way interactions, and main effects with all interactions were compared using Akaike's information criterion (AIC). 


\section{Results}

\section{Viral RNA shedding by nasally infected cottontail rabbits}

All eighteen cottontail rabbits in the nasal treatment groups, regardless of inoculation dose (e.g., $10^{2}, 10^{3}$, or $10^{4} \mathrm{EID}_{50}$ ), shed viral RNA nasally on multiple DPI. Of interest, IAV replicated successfully in all animals in the nasal $10^{2} \mathrm{EID}_{50}$ inoculation group, and with the exception of one animal, all shed viral RNA via the nasal and oral routes (Fig. 1). Notably, one animal in this low dose treatment group shed $>10^{7}$
PCR EID E0 equivalent $/ \mathrm{mL}$ on 3 DPI. Shedding in the two other nasal treatment groups typically began at an earlier time point (Fig. 1), and the majority of the animals in these groups shed $>10^{6}$ PCR EID $_{50}$ equivalent $/ \mathrm{mL}$ on at least one occasion.

\section{Viral RNA shedding by orally infected cottontail rabbits}

Results from the oral treatment groups were more variable. For example, none of six, four of six, and three of six (Fig. 2) animals in the $10^{2}, 10^{3}$, and $10^{4} \mathrm{EID}_{50}$ oral inoculation
Fig. 1 Nasal and oral shedding of cottontail rabbits (Sylvilagus sp.) experimentally infected with approximately $10^{2}, 10^{3}$, and $10^{4} \mathrm{EID}_{50}$ of a low pathogenic avian influenza A virus by the nasal route. Nasal and oral samples were collected on odd days post infection (DPI) for one-half of each treatment group and on even days for the other one-half of each treatment group. Horizontal bars represent medians and vertical lines represent the minimum and maximum quantities detected on a given DPI

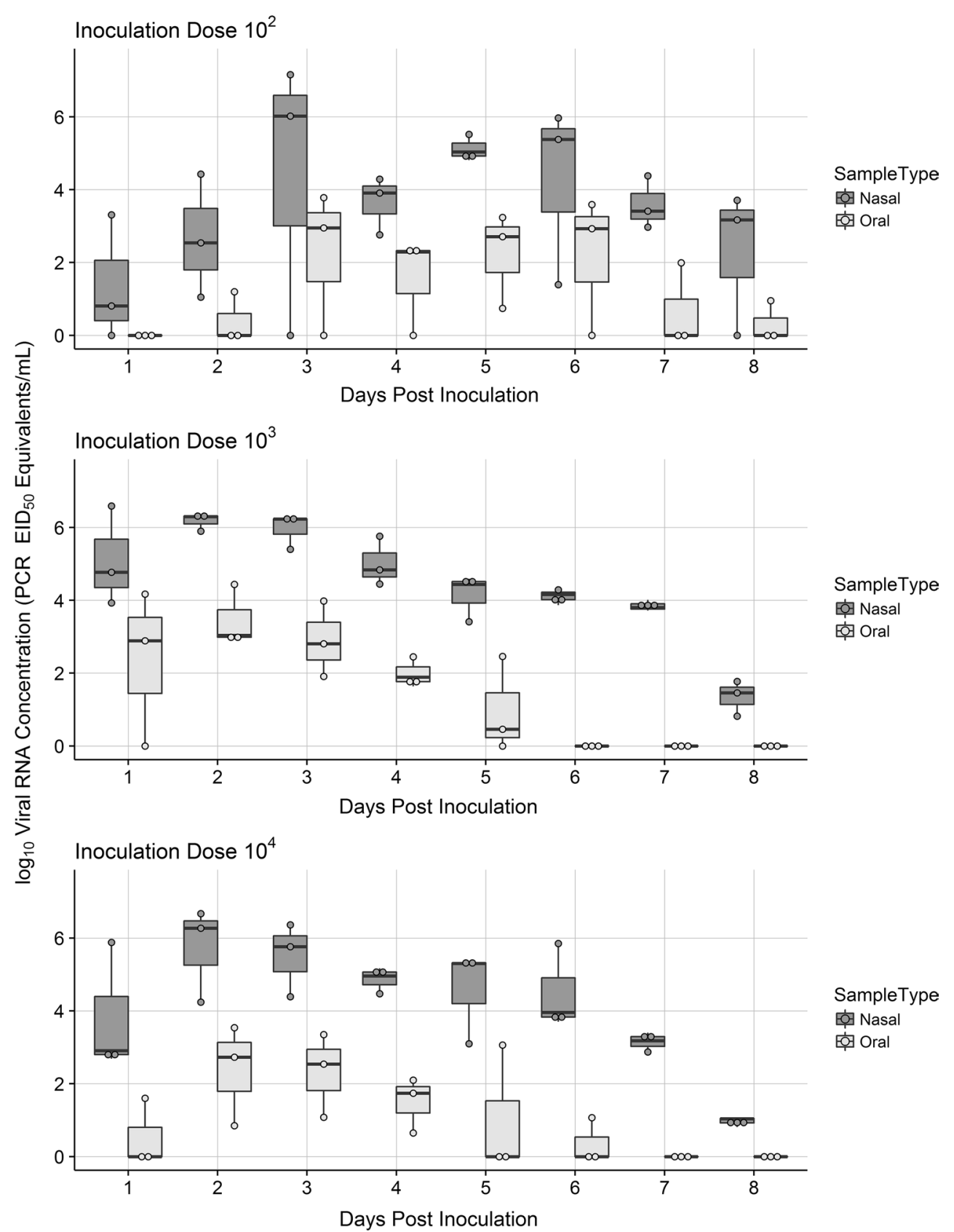


Fig. 2 Nasal and oral shedding of cottontail rabbits (Sylvilagus sp.) experimentally infected with approximately $10^{2}, 10^{3}$, and $10^{4} \mathrm{EID}_{50}$ of a low pathogenic avian influenza $\mathrm{A}$ virus by the oral route. Nasal and oral samples were collected on odd days post infection (DPI) for one-half of each treatment group and on even days for the other one-half of each treatment group. Horizontal bars represent medians and vertical lines represent the minimum and maximum quantities detected on a given DPI

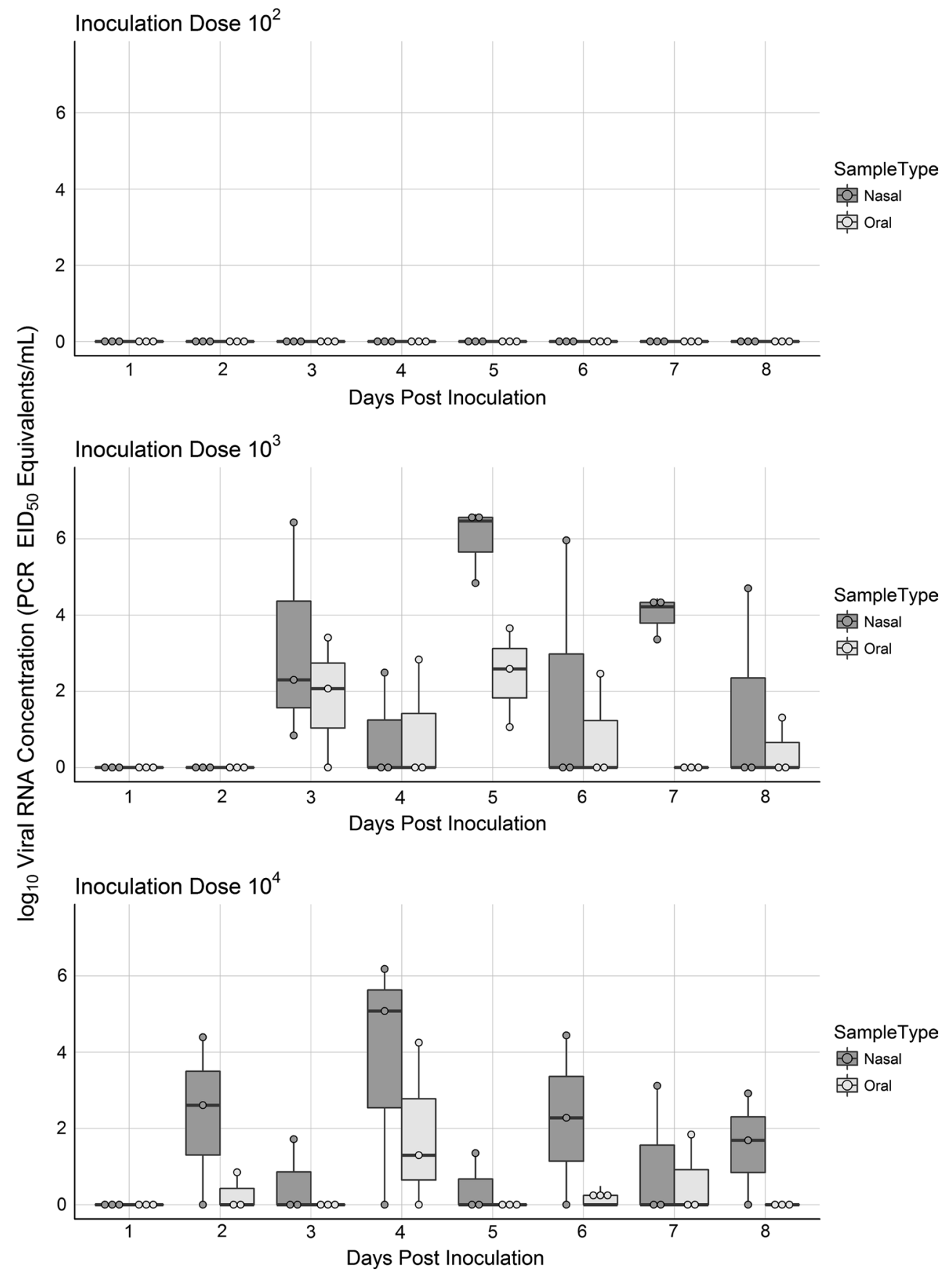

treatment groups, respectively, shed viral RNA on at least one occasion. In addition, high levels of individual heterogeneity were noted in orally treated animals. For example, although some animals from these groups shed viral RNA nasally at levels of $>10^{6.0} \mathrm{PCR}^{\mathrm{EID}} \mathrm{F}_{50}$ equivalent $/ \mathrm{mL}$, others produced much lower levels of shedding, and some did not shed any detectable virus during the experiment. In general, nasal shedding was more pronounced than oral shedding in these groups. In addition, cottontail rabbits exposed to IAV by the oral route tended to initiate shedding 1-2 days later than those inoculated by the nasal route (Fig. 1 and 2).
Of interest, oral shedding was not detected in the $10^{2}$ nasal treatment group until 2 DPI (Fig. 1), which is in contrast to the other two dosage groups (Fig. 1).

\section{Data analysis}

The regression model that included the main effects (DOSE, ROUTE, and SAMPLE TYPE) and all two-way interactions between them had the lowest AIC score and an Akaike weight of 0.7 (Table 1), indicating that this model best explains the data. The model without variable interactions 
Table 1 Model selection results comparing the full model with no interaction between the variables, a full model with all two-way interactions, and a full model with all interactions

\begin{tabular}{|c|c|c|c|c|}
\hline Model & K & AIC & $\Delta \mathrm{AIC}$ & AIC weight \\
\hline $\begin{array}{l}\text { Full Model - no interactions } \\
\text { DOSE + ROUTE + SAMPLE TYPE }\end{array}$ & 5 & 269.4 & 19.5 & 0.0 \\
\hline $\begin{array}{l}\text { Full - all two-way interactions } \\
\text { DOSE + ROUTE + SAMPLE TYPE + DOSE*ROUTE + DOSE*SAMPLE TYPE + ROUTE*SAMPLE } \\
\text { TYPE }\end{array}$ & 8 & 249.9 & 0 & 0.7 \\
\hline $\begin{array}{l}\text { Full }- \text { all interactions } \\
\text { DOSE + ROUTE + SAMPLE TYPE + DOSE*ROUTE + DOSE*SAMPLE TYPE + ROUTE*SAMPLE } \\
\text { TYPE + DOSE*ROUTE*SAMPLE TYPE }\end{array}$ & 9 & 251.6 & 1.7 & 0.3 \\
\hline
\end{tabular}

The variables tested are inoculation dose (DOSE), inoculation route (ROUTE), and sample type (SAMPLE TYPE)

Table 2 Model output for the mixed-effect linear regression model of total RNA output as a function of inoculation dose (DOSE), inoculation route (ROUTE), and sample type (SAMPLE TYPE), and all two-way interactions between these variables

\begin{tabular}{lclrr}
\hline Fixed effects & Estimate & Std. error & $t$-value & $\operatorname{Pr}(>|t|)$ \\
\hline (Intercept) & 4.468 & 1.298 & 3.443 & 0.001 \\
DOSE & 0.258 & 0.416 & 0.620 & 0.539 \\
ROUTE (Oral) & -5.577 & 1.778 & -3.137 & 0.003 \\
SAMPLE TYPE (Oral) & -1.507 & 0.690 & -2.183 & 0.036 \\
DOSE* ROUTE & 0.749 & 0.569 & 1.317 & 0.196 \\
DOSE*SAMPLE TYPE & -0.474 & 0.215 & -2.208 & 0.034 \\
ROUTE *SAMPLE TYPE & 1.884 & 0.351 & 5.372 & $<0.001$ \\
\hline
\end{tabular}

had a $\triangle$ AIC value of 19.5, suggesting that the interactions between the variables are important. The route of inoculation had a significant impact on the total amount of RNA shed $(p=0.003)$ with significantly higher shedding levels observed for nasal inoculations than for oral inoculations (Table 2). Similarly, significantly more RNA was found in nasal washes than in oral swabs $(p<0.001)$, and there was a significant interaction between these two variables. Inoculation dose did not show a significant effect on the total amount of RNA shed, but the interaction term between inoculation dose and sample type was significant $(p=0.037)$, and this relationship likely reflects the result that cottontails orally inoculated with $10^{2} \mathrm{EID}_{50}$ did not become infected.

\section{Serology}

All animals used in the experiment were determined to be negative for antibodies to IAV prior to the initiation of the experiment (Table 3). Each of the nasally infected cottontail rabbits developed a serologic response by 18 DPI, regardless of the dose they received (Table 3). Results associated with the oral route of infection were more variable, as 0 of 6,4 of 6 , and 4 of 6 individuals from the $10^{2}, 10^{3}$, and $10^{4}$ EID $_{50}$ treatment groups, respectively, developed a serological response. In general, animals that shed virus by at least one route on at least one day seroconverted by the end of the experiment. One exception was noted in the $10^{4} \mathrm{EID}_{50}$ oral treatment group, as a single cottontail that exhibited no detectable shedding during any sampling period did develop a weak positive antibody response by the end of the experiment. Thus, it is likely that this animal was exposed to enough virus to elicit a weak immune response but not enough to initiate detectable viral replication. However, considering that the animals were only sampled every other day, this animal could have shed during a day when sampling was not conducted.

\section{Clinical signs of disease}

As has been reported previously for cottontail rabbits infected with H4 LP IAV [18], no observable clinical signs of disease were noted in any of the animals. This is in contrast to a study of cottontail rabbits infected with emergent H7N9 IAV, where most experimentally infected animals developed mild clinical signs of disease [20].

\section{Discussion}

Considering that all cottontail rabbits in the $10^{2} \operatorname{EID}_{50}$ nasal inoculation treatment group seroconverted and shed virus on at least one occasion, their minimum infectious dose by this route of infection is quite low, possibly well below the lowest dose used in the current study. Although the minimum infectious dose by the oral route was higher $\left(10^{3}\right.$ EID $\left._{50}\right)$, IAV concentrations of $\geq 10^{3}$ EID $_{50}$ per $\mathrm{mL}$ have been routinely detected in pond water collected during experimental infection studies involving waterfowl [1, 25], and IAVs have been routinely detected in natural bodies of water $[10,13]$. This suggests that in some instances, a single drink from a small IAV-contaminated body of water associated with recent waterfowl activity could be sufficient to initiate viral infection in cottontail rabbits. Further, the probability of infection of cottontail rabbits 
Table 3 Serology of cottontail rabbits (Sylvilagus sp.) experimentally infected with multiple doses of a low-pathogenic avian influenza A virus by the nasal and oral routes of infection

\begin{tabular}{|c|c|c|c|c|c|}
\hline \multirow[t]{2}{*}{ Rack } & \multirow[t]{2}{*}{ Dose $^{a}$} & \multirow{2}{*}{$\begin{array}{l}\text { Infec- } \\
\text { tion } \\
\text { route }^{b}\end{array}$} & \multirow{2}{*}{$\begin{array}{l}\text { Viral } \\
\text { RNA } \\
\text { shed }^{\text {c }}\end{array}$} & \multicolumn{2}{|l|}{ Serologyd } \\
\hline & & & & Pre-experiment & 18 DPI \\
\hline 1 & $10^{2}$ & $\mathrm{O}$ & $\mathrm{N}$ & Negative & Negative \\
\hline 1 & $10^{2}$ & $\mathrm{O}$ & $\mathrm{N}$ & Negative & Negative \\
\hline 1 & $10^{2}$ & $\mathrm{O}$ & $\mathrm{N}$ & Negative & Negative \\
\hline 1 & $10^{2}$ & $\mathrm{O}$ & $\mathrm{N}$ & Negative & Negative \\
\hline 1 & $10^{2}$ & $\mathrm{O}$ & $\mathrm{N}$ & Negative & Negative \\
\hline 1 & $10^{2}$ & $\mathrm{O}$ & $\mathrm{N}$ & Negative & Negative \\
\hline 2 & $10^{2}$ & $\mathrm{~N}$ & $\mathrm{Y}$ & Negative & Weak positive \\
\hline 2 & $10^{2}$ & $\mathrm{~N}$ & $\mathrm{Y}$ & Negative & Strong positive \\
\hline 2 & $10^{2}$ & $\mathrm{~N}$ & $\mathrm{Y}$ & Negative & Strong positive \\
\hline 2 & $10^{2}$ & $\mathrm{~N}$ & $\mathrm{Y}$ & Negative & Positive \\
\hline 2 & $10^{2}$ & $\mathrm{~N}$ & $\mathrm{Y}$ & Negative & Strong positive \\
\hline 2 & $10^{2}$ & $\mathrm{~N}$ & $\mathrm{Y}$ & Negative & Positive \\
\hline 3 & $10^{3}$ & $\mathrm{O}$ & $\mathrm{Y}$ & Negative & Positive \\
\hline 3 & $10^{3}$ & $\mathrm{O}$ & $\mathrm{Y}$ & Negative & Positive \\
\hline 3 & $10^{3}$ & $\mathrm{O}$ & $\mathrm{Y}$ & Negative & Strong positive \\
\hline 3 & $10^{3}$ & $\mathrm{O}$ & $\mathrm{Y}$ & Negative & Positive \\
\hline 3 & $10^{3}$ & $\mathrm{O}$ & $\mathrm{N}$ & Negative & Negative \\
\hline 3 & $10^{3}$ & $\mathrm{O}$ & $\mathrm{N}$ & Negative & Negative \\
\hline 4 & $10^{3}$ & $\mathrm{~N}$ & $\mathrm{Y}$ & Negative & Positive \\
\hline 4 & $10^{3}$ & $\mathrm{~N}$ & $\mathrm{Y}$ & Negative & Positive \\
\hline 4 & $10^{3}$ & $\mathrm{~N}$ & $\mathrm{Y}$ & Negative & Positive \\
\hline 4 & $10^{3}$ & $\mathrm{~N}$ & $\mathrm{Y}$ & Negative & Positive \\
\hline 4 & $10^{3}$ & $\mathrm{~N}$ & $\mathrm{Y}$ & Negative & Positive \\
\hline 4 & $10^{3}$ & $\mathrm{~N}$ & $\mathrm{Y}$ & Negative & Positive \\
\hline 5 & $10^{4}$ & $\mathrm{O}$ & $\mathrm{N}$ & Negative & Negative \\
\hline 5 & $10^{4}$ & $\mathrm{O}$ & $\mathrm{Y}$ & Negative & Strong positive \\
\hline 5 & $10^{4}$ & $\mathrm{O}$ & $\mathrm{N}$ & Negative & Weak positive \\
\hline 5 & $10^{4}$ & $\mathrm{O}$ & $\mathrm{N}$ & Negative & Negative \\
\hline 5 & $10^{4}$ & $\mathrm{O}$ & $\mathrm{Y}$ & Negative & Strong positive \\
\hline 5 & $10^{4}$ & $\mathrm{O}$ & $\mathrm{Y}$ & Negative & Strong positive \\
\hline 6 & $10^{4}$ & $\mathrm{~N}$ & $\mathrm{Y}$ & Negative & Strong positive \\
\hline 6 & $10^{4}$ & $\mathrm{~N}$ & $\mathrm{Y}$ & Negative & Strong positive \\
\hline 6 & $10^{4}$ & $\mathrm{~N}$ & $\mathrm{Y}$ & Negative & Strong positive \\
\hline 6 & $10^{4}$ & $\mathrm{~N}$ & $\mathrm{Y}$ & Negative & Strong positive \\
\hline 6 & $10^{4}$ & $\mathrm{~N}$ & $\mathrm{Y}$ & Negative & Strong positive \\
\hline 6 & $10^{4}$ & $\mathrm{~N}$ & $\mathrm{Y}$ & Negative & Positive \\
\hline
\end{tabular}

${ }^{\text {a }}$ Dose $=$ approximately $10^{2}, 10^{3}$, or $10^{4} \log _{10}$ EID $_{50}$ of IAV delivered in BA-1

${ }^{\mathrm{b}} \mathrm{O}=$ oral and $\mathrm{N}=$ nasal

${ }^{c}$ Shedding: $\mathrm{N}=$ did not shed; $\mathrm{Y}=$ shedding was detected on at least one occasion

d Pre-experiment and 18 DPI serum samples were analyzed with standard AGID tests (see "Materials and methods") may be even higher than shown in the current study, as an individual could use the same contaminated water source multiple times, thereby increasing the likelihood of infection due to multiple exposures.

Peak shedding observed in this study generally occurred at later time points with low inoculation doses than with higher doses (1-2 DPI) such as $10^{6} \mathrm{EID}_{50}$ [18]. This observation was especially pronounced for the $10^{2} \mathrm{EID}_{50}$ treatment group, which peaked at 5-6 DPI for nasal samples (Fig. 1). In addition, the initiation of shedding by orally inoculated animals tended to lag behind that of nasally inoculated animals by 1-2 days (Fig. 1 and 2). Furthermore, in the orally inoculated animals individual heterogeneity was pronounced and differences in the animals sampled on odd and even days were evident (Fig. 2).

Although a strong effect of dose was not observed in our models, this may have been due to the fact that, in our regression models, we evaluated the total amount of RNA shed, which may have minimized differences. For example, when the $10^{2}$ nasal inoculation cohort is compared to the $10^{3}$ and $10^{4}$ groups, the peak output is much later for the former, but the overall amount of viral RNA shed across the sampling period is similar (Fig. 1).

In general terms, delayed virus shedding associated with the oral route of infection in certain mammal species may be of epidemiological significance. For example, cottontail rabbits infected by the oral route did not initiate shedding until 2-3 DPI, but when infected, eventually shed virus at nearly equal, and in some instances, greater quantities than their nasally infected counterparts (Fig. 2). In addition, some animals were still shedding moderately high quantities of virus at $8 \mathrm{DPI}$, which is in contrast to those that were inoculated nasally at higher doses in a previous study [18]. Thus, this delayed initiation of virus shedding, as well as shedding at later time points, suggests that cottontail rabbits orally infected with IAV would reach peak shedding a few days after exposure, which would allow them sufficient time intervals to contaminate additional environments.

It has been proposed that mammals sharing habitats with waterfowl could become infected with various IAVs [7, 11]. Once infected, a cottontail rabbit could contaminate a new area, such as a poultry facility, with IAV. For example, if a rabbit were to consume water or food contaminated by waterfowl at ponds associated with a poultry facility, the animal could then move the virus within close proximity of the facility, dependent, of course, on the biosecurity practices at the facility. Ponds created to collect facility effluents, as well as for aesthetic purposes, are commonplace near some poultry facilities and can attract waterfowl. An additional 
scenario is that a cottontail rabbit could transport a virus from a nearby farm to an intermittent water source in close proximity to a barn where a farm worker or equipment is more likely to become contaminated.

These findings also have implications for live-bird markets. Considering that cottontail rabbits can be commonly found at some live-bird markets [4], the observation of their oral susceptibility could have implications for IAVs in these types of settings. For example, because rabbits have been observed to be susceptible to relatively low doses by the oral route, they could become infected by consuming virus-laden feed or water spilled from another cage housing poultry.

Cottontail rabbits showed a relatively low minimum infectious dose by the oral route during the current study. This is in contrast to raccoons (Procyon lotor), as free access to water pans spiked with $10^{5}$ and $10^{3.2} \mathrm{EID}_{50} /$ $\mathrm{mL}$ of IAV only resulted in transmission to a fraction of raccoons experimentally tested with the higher dose of water [16], thereby suggesting that raccoons require a higher inoculation dose for successful infection, presumably via the oral route, when compared to cottontail rabbits. Nonetheless, raccoons have been commonly shown to have antibody responses to IAV in multiple regions in their native range [7] as well as in introduced populations elsewhere [8], suggesting that a sufficient mechanism for their infection exists but may not be well described at this time. Similar large-scale serological surveys have not been conducted on cottontail rabbits. Overall, the generality of successful orally-acquired IAV infections in mammals may be an important question to address in future studies.

The present study has shown that cottontail rabbits are susceptible to infection with IAV at low doses. The oral route of infection, although less efficient in this species, is likely to be a more probable natural infection route than nasal exposure. Nonetheless, inadvertent nasal exposures while utilizing a body of water have been suggested for other mammal species [16]. As has been suggested previously $[18,19]$, cottontail rabbits should be taken into account in the biosecurity plans of poultry facilities.

Acknowledgements We thank the National Wildlife Research Center (NWRC) animal care staff for excellent assistance. The opinions and conclusions of this article are those of the authors and do necessarily represent those of the U.S. Department of Agriculture. The mention of commercial products herein is for identification purposes only and does not constitute endorsement or censure.

\section{Compliance with ethical standards}

Funding This research was supported by the U.S. Department of Agriculture.

Conflict of interest The authors declare that they have no conflict of interest.
Ethical approval All applicable international, national, and/or institutional guidelines for the care and use of animals were followed.

\section{References}

1. Achenbach JE, Bowen RA (2011) Transmission of avian influenza A viruses among species in an artificial barnyard. PLoS One 6:e17643

2. Armstrong DM, Fitzgerald JP, Meaney CA (2011) Mammals of Colorado, 2nd edn. University Press of Colorado, Boulder

3. Bentler KT, Gossett DN, Root JJ (2012) A novel isoflurane anesthesia induction system for raccoons. Wildl Soc Bull 36:807-812

4. Bulaga LL, Garber L, Senne DA, Myers TJ, Good R, Wainwright S, Trock S, Suarez DL (2003) Epidemiologic and surveillance studies on avian influenza in live-bird markets in New York and New Jersey, 2001. Avian Dis 47:996-1001

5. Cui P, Hou Y, Xing Z, He Y, Li T, Guo S, Luo Z, Yan B, Yin Z, Lei $F$ (2011) Bird migration and risk for H5N1 transmission into Qinghai Lake, China. Vector Borne Zoonotic Dis 11:567-576

6. Guan Y, Farooqui A, Zhu H, Dong W, Wang J, Kelvin DJ (2013) H7N9 Incident, immune status, the elderly and a warning of an influenza pandemic. J Infect Dev Ctries 7:302-307

7. Hall JS, Bentler KT, Landolt G, Elmore SA, Minnis RB, Campbell TA, Barras SC, Root JJ, Pilon J, Pabilonia K, Driscoll C, Slate D, Sullivan H, McLean RG (2008) Influenza infection in wild raccoons. Emerg Infect Dis 14:1842-1848

8. Horimoto T, Maeda K, Murakami S, Kiso M, Iwatsuki-Horimoto K, Sashika M, Ito T, Suzuki K, Yokoyama M, Kawaoka Y (2011) Highly pathogenic avian influenza virus infection in feral raccoons, Japan. Emerg Infect Dis 17:714-717

9. Ip HS, Torchetti MK, Crespo R, Kohrs P, DeBruyn P, Mansfield KG, Baszler T, Badcoe L, Bodenstein B, Shearn-Bochsler V, Killian ML, Pedersen JC, Hines N, Gidlewski T, DeLiberto T, Sleeman JM (2015) Novel Eurasian highly pathogenic influenza A H5 viruses in wild birds, Washington, USA, 2014. Emerg Infect Dis 21:886-890

10. Ito T, Okazaki K, Kawaoka Y, Takada A, Webster RG, Kida H (1995) Perpetuation of influenza A viruses in Alaskan waterfowl reservoirs. Arch Virol 140:1163-1172

11. Kajihara M, Matsuno K, Simulundu E, Muramatsu M, Noyori O, Manzoor R, Nakayama E, Igarashi M, Tomabechi D, Yoshida R, Okamatsu M, Sakoda Y, Ito K, Kida H, Takada A (2011) An H5N1 highly pathogenic avian influenza virus that invaded Japan through waterfowl migration. Jpn J Vet Res 59:89-100

12. NVSL (2003) Avian influenza agar gel immunodiffusion test to detect serum antibodies to type A influenza viruses. NVSL document AVPRO0100.05

13. Okuya K, Kawabata T, Nagano K, Tsukiyama-Kohara K, Kusumoto I, Takase K, Ozawa M (2015) Isolation and characterization of influenza A viruses from environmental water at an overwintering site of migratory birds in Japan. Arch Virol 160:3037-3052

14. Piaggio AJ, Shriner SA, VanDalen KK, Franklin AB, Anderson TD, Kolokotronis SO (2012) Molecular surveillance of low pathogenic avian influenza viruses in wild birds across the United States: inferences from the hemagglutinin gene. PLoS One 7:e50834

15. ProMED-mail (2015) Avian influenza (68): USA (Minnesota, South Dakota) HPAI H5N2, Turkeys. ProMed-Mail 20150405.3277704

16. Root JJ, Bentler KT, Shriner SA, Mooers NL, VanDalen KK, Sullivan HJ, Franklin AB (2014) Ecological routes of avian 
influenza virus transmission to a common mesopredator: an experimental evaluation of alternatives. PLoS One 9:e102964

17. Root JJ, Shriner SA, Bentler KT, Gidlewski T, Mooers NL, Ellis JW, Spraker TR, VanDalen KK, Sullivan HJ, Franklin AB (2014) Extended viral shedding of a low pathogenic avian influenza virus by striped skunks (Mephitis mephitis). PLoS One 9:e70639

18. Root JJ, Shriner SA, Bentler KT, Gidlewski T, Mooers NL, Spraker TR, VanDalen KK, Sullivan HJ, Franklin AB (2014) Shedding of a low pathogenic avian influenza virus in a common synanthropic mammal-the cottontail rabbit. PLoS One 9:e103513

19. Root JJ, Shriner SA, Ellis JW, VanDalen KK, Sullivan HJ, Franklin AB (2015) When fur and feather occur together: interclass transmission of avian influenza A virus from mammals to birds through common resources. Sci Rep 5:12354

20. Root JJ, Bosco-Lauth AM, Bielefeldt-Ohmann H, Bowen RA (2016) Experimental infection of peridomestic mammals with emergent H7N9 (A/Anhui/1/2013) influenza A virus: implications for biosecurity and wet markets. Virology 487:242-248

21. Shriner SA, VanDalen KK, Mooers NL, Ellis JW, Sullivan HJ, Root JJ, Franklin AB (2012) Low-pathogenic avian influenza viruses in wild house mice. PLoS One 7:e39206

22. Spackman E, Senne DA, Bulaga LL, Myers TJ, Perdue ML, Garber LP, Lohman K, Daum LT, Suarez DL (2003) Development of real-time RT-PCR for the detection of avian influenza virus. Avian Dis $47: 1079-1082$

23. Sullivan HJ, Blitvich BJ, VanDalen K, Bentler KT, Franklin AB, Root JJ (2009) Evaluation of an epitope-blocking enzyme-linked immunosorbent assay for the detection of antibodies to influenza A virus in domestic and wild avian and mammalian species. $\mathbf{J}$ Virol Methods 161:141-146

24. Team RDC (2010) R: A Language and Environment for Statistical Computing. R Foundation for Statistical Computing, Vienna

25. VanDalen KK, Franklin AB, Mooers NL, Sullivan HJ, Shriner SA (2010) Shedding light on avian influenza H4N6 infection in mallards: modes of transmission and implications for surveillance. PLoS One 5:e12851

26. Wang G, Zhan D, Li L, Lei F, Liu B, Liu D, Xiao H, Feng Y, Li J, Yang B, Yin Z, Song X, Zhu X, Cong Y, Pu J, Wang J, Liu J, Gao GF, Zhu Q (2008) H5N1 avian influenza re-emergence of Lake Qinghai: Phylogenetic and antigenic analyses of the newly isolated viruses and roles of migratory birds in virus circulation. J Gen Virol 89:697-702

27. Yee KS, Carpenter TE, Mize S, Cardona CJ (2008) The live bird market system and low-pathogenic avian influenza prevention in Southern California. Avian Dis 52:348-352

28. Yu Z, Cheng K, Sun W, Xin Y, Cai J, Ma R, Zhao Q, Li L, Huang J, Sang X, Li X, Zhang K, Wang T, Qin C, Qian J, Gao Y, Xia X (2014) Lowly pathogenic avian influenza (H9N2) infection in Plateau pika (Ochotona curzoniae), Qinghai Lake, China. Vet Microbiol 173:132-135

29. Zhou J, Sun W, Wang J, Guo J, Yin W, Wu N, Li L, Yan Y, Liao M, Huang Y, Luo K, Jiang X, Chen H (2009) Characterization of the H5N1 highly pathogenic avian influenza virus derived from wild pikas in China. J Virol 83:8957-8964 